\title{
Estimation of coarse dead wood stocks in intact and degraded forests in the Brazilian Amazon using airborne lidar
}

\author{
Marcos A. S. Scaranello ${ }^{1}$, Michael Keller ${ }^{1,2,3}$, Marcos Longo ${ }^{1,3}$, Maiza N. dos-Santos ${ }^{1}$, Veronika Leitold ${ }^{4}$, \\ Douglas C. Morton ${ }^{4}$, Ekena R. Pinagé ${ }^{5,6}$, and Fernando Del Bon Espírito-Santo ${ }^{7,8}$ \\ ${ }^{1}$ Embrapa Informática Agropecuária, Embrapa, Campinas, 13083-886, Brazil \\ ${ }^{2}$ International Institute of Tropical Forestry, USDA Forest Service, Río Piedras, 00926-1119, Puerto Rico \\ ${ }^{3}$ Jet Propulsion Laboratory, California Institute of Technology, Pasadena, CA 91109, USA \\ ${ }^{4}$ NASA Goddard Space Flight Center, NASA, Greenbelt, MD 20771, USA \\ ${ }^{5}$ School of Life Sciences, University of Technology Sydney, Sydney, 2007, Australia \\ ${ }^{6}$ College of Forestry, Oregon State University, Corvallis, OR 97331, USA \\ ${ }^{7}$ Leicester Institute of Space and Earth Observation, Centre for Landscape and Climate Research, School of Geography, \\ Geology and Environment, University of Leicester, University Road, Leicester LE1 7RH, UK \\ ${ }^{8}$ Faculdade de Filosofia, Ciências e Letras de Ribeirão Preto, Universidade de São Paulo, \\ Ribeirão Preto, 14040-900, Brazil
}

Correspondence: Marcos A. S. Scaranello (masscaranello@gmail.com)

Received: 2 March 2019 - Discussion started: 8 April 2019

Revised: 31 July 2019 - Accepted: 6 August 2019 - Published: 13 September 2019

\begin{abstract}
Coarse dead wood is an important component of forest carbon stocks, but it is rarely measured in Amazon forests and is typically excluded from regional forest carbon budgets. Our study is based on line intercept sampling for fallen coarse dead wood conducted along 103 transects with a total length of $48 \mathrm{~km}$ matched with forest inventory plots where standing coarse dead wood was measured in the footprints of larger areas of airborne lidar acquisitions. We developed models to relate lidar metrics and Landsat time series variables to coarse dead wood stocks for intact, logged, burned, or logged and burned forests. Canopy characteristics such as gap area produced significant individual relations for logged forests. For total fallen plus standing coarse dead wood (hereafter defined as total coarse dead wood), the relative root mean square error for models with only lidar metrics ranged from $33 \%$ in logged forest to up to $36 \%$ in burned forests. The addition of historical information improved model performance slightly for intact forests $(31 \%$ against $35 \%$ relative root mean square error), not justifying the use of a number of disturbance events from historical satellite images (Landsat) with airborne lidar data. Lidarderived estimates of total coarse dead wood compared favorably with independent ground-based sampling for areas up to
\end{abstract}

several hundred hectares. The relations found between total coarse dead wood and variables quantifying forest structure derived from airborne lidar highlight the opportunity to quantify this important but rarely measured component of forest carbon over large areas in tropical forests.

\section{Introduction}

Intact and disturbed tropical forests play a critical role in the global carbon cycle (Pan et al., 2011). From 1990 through 2007 , tropical forests contributed about $46 \%$ of the global carbon sink (Schimel et al., 2015). The largest remaining area of tropical forest in the Amazon region contains about $50 \%$ of the carbon stored in all tropical forests or about $60 \mathrm{PgC}$ in the living aboveground biomass pool (Saatchi et al., 2011; Baccini et al., 2012). The Brazilian Amazon retains about $80 \%$ of its original forest cover (PRODES-INPE, 2016) and while deforestation rates in Brazil have decreased by about $70 \%$ since 2004 (PRODES-INPE, 2016), forest degradation processes including logging, fire, and fragmentation continue to deplete carbon stocks. 
Forest degradation is accelerating the rate of tree mortality across the tropics (McDowell et al., 2018), leading to severe loss of live aboveground biomass (AGB) (Berenguer et al., 2014; Cochrane, 2003; Longo et al., 2016; Rappaport et al., 2018). In several areas of the tropics, the AGB decreased dramatically after multiple events of forest degradation (logging, burning, burning and logging). In the central and eastern Brazilian Amazon the AGB decreased between $18 \%-24 \%$ and $35 \%-55 \%$ in the Santarém and Paragominas regions, respectively. On the other hand, forest degradation promotes the increase in coarse dead wood (CDW) at the forest floor. The stocks of CDW increase substantially after forest disturbance by logging and fire.

In the short term, the stocks of CDW increase substantially after forest disturbance by logging and fire. For example, fallen CDW stocks increased from $55 \mathrm{Mg} \mathrm{ha}^{-1}$ in intact forest to $75 \mathrm{Mg} \mathrm{ha}^{-1}$ with reduced-impact logging, and to almost $110 \mathrm{Mg} \mathrm{ha}^{-1}$ in a conventionally logged forest in Paragominas Municipality (Keller et al., 2004). The importance of CDW is magnified in degraded tropical forests (Alamgir et al., 2016). In degraded forests, CDW stocks can exceed the live aboveground biomass pool (Gerwing, 2002; Palace et al., 2012). Quantifying the spatial and temporal variability of CDW production and decay is therefore critical to constrain the magnitude and timing of carbon emissions from forest degradation or climate anomalies such as droughts (Leitold et al., 2018).

CDW stocks and the rates of decay of CDW constitute large uncertainties in the carbon cycle budget of the Amazon (Aguiar et al., 2012). We have a limited understanding of how CDW of intact and degraded tropical forests varies across space and time. Traditional forest inventories provide important sources of information for understanding carbon cycling, but measurements of CDW in tropical forests are rare, labor intensive, and prohibitively costly for large areas (Chao et al., 2009). As an alternative, lidar (light detection and ranging) remote sensing offers the possibility to quantify AGB and CDW over large areas. In contrast to AGB where a large number of studies have been developed (e.g., Nelson et al., 1988; Næsset et al., 2006; Nelson, 2010; Asner et al., 2012; Longo et al., 2016), few studies have focused on lidar remote sensing of CDW and, based on a recent comprehensive review (Marchi et al., 2018), none has been conducted in intact or degraded tropical forest.

Here, we combine a large dataset of airborne lidar (14 870 ha), Landsat images, and forest inventories of CDW at 14 sites spread across the Brazilian Amazon. Using airborne remote-sensing data, we developed the first lidarderived estimates of CDW for intact and degraded tropical forests including areas that have been logged, burned, and fragmented by deforestation for agricultural expansion. We constructed two groups of models containing (1) only lidarderived metrics or (2) historical information from Landsat imagery, ecological variables extracted from lidar data, and lidar metrics. For the historical models (2), we hypothesized that the CDW stock increases with the number of degradation events (Cochrane et al., 1999) and decreases with age since the last degradation event (Chambers et al., 2000). Additionally, we expected that the CDW stock increases with the increasing gap area (Espírito-Santo et al., 2014a) and with forest canopy height, a correlate of live aboveground biomass (Longo et al., 2016) because aboveground live biomass was significantly correlated with CDW across the Amazon (Chao et al., 2008).

\section{Material and methods}

\subsection{Study sites}

As part of the Sustainable Landscapes Brazil project, we collected airborne lidar, forest inventories and measurements of CDW across five states of the Brazilian Legal Amazon (Pará, Amazonas, Mato Grosso, Rondônia, and Acre) (Fig. 1). The airborne lidar data used in this study were collected between 2012 and 2015, covered a total area of 14870 ha, and overlapped with $103 \mathrm{CDW}$ transects $(48 \mathrm{~km}$ of total length sampled within 6 months of the lidar airborne campaigns). All ground sampling locations were wholly contained in the airborne lidar areas of interest. Our sites included two forest types (dense and open evergreen forests) with a moderate climatic variation (precipitation between 1750 and $2450 \mathrm{~mm} \mathrm{yr}^{-1}$ ), and a large number of disturbance events and processes (Table 1). The dry season length (defined as months with precipitation $\leq 100 \mathrm{~mm}$ per month) varies from 5 months in the Tanguro (TAN), Feliz Natal (FNA), and Tapajós (TAP) regions to 3 months in Reserva Adolpho Ducke (DUC). We sampled intact forests as well as forest disturbed by reduced-impact logging, conventional logging, understory fire, and combinations of logging and fire. We quantified the number of disturbance events and land use types using historical Landsat images from between 1984 and 2013 (Longo et al., 2016). We inspected all images using the normalized difference vegetation index (NDVI) and the normalized burn ratio (NBR). We classified the sites into five categories with increasing levels of disturbance: intact, reduced-impact logging, conventional logging, burned, and logged and burned. We summarized disturbance history by counting the number of degradation events and the time (years) since the last degradation event.

\subsection{Line intercept sampling of fallen CDW}

For this study, we define CDW as material greater than $10 \mathrm{~cm}$ in diameter as opposed to fine dead wood $(\leq 10 \mathrm{~cm})$ (Harmon et al., 1995). We used the line intercept method for estimating fallen CDW volume (Brown, 1974; Keller et al., 2004; Palace et al., 2007). The line intercept method is a strip sample of infinitesimal width, and the data collected in the field are the diameters of wood pieces at their points of intersection with the plane perpendicular to the ground above the line (Brown, 


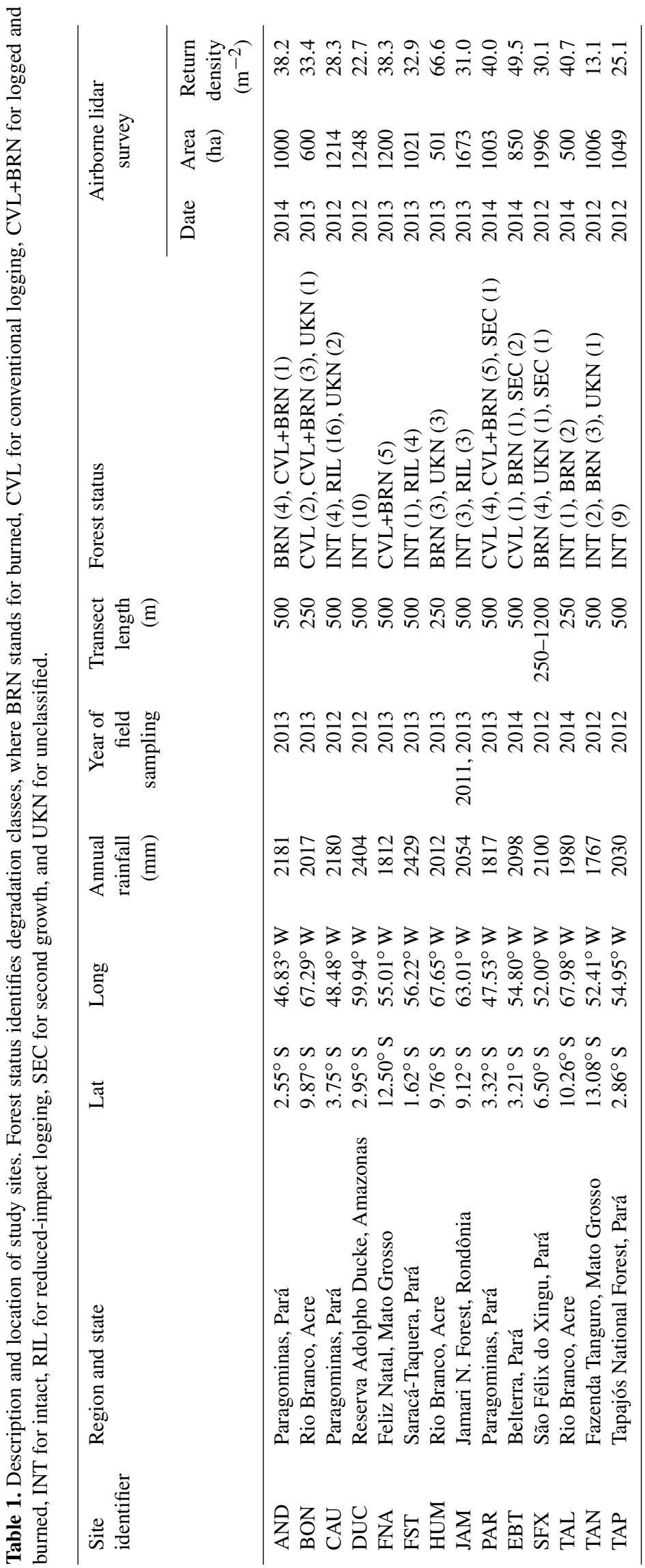




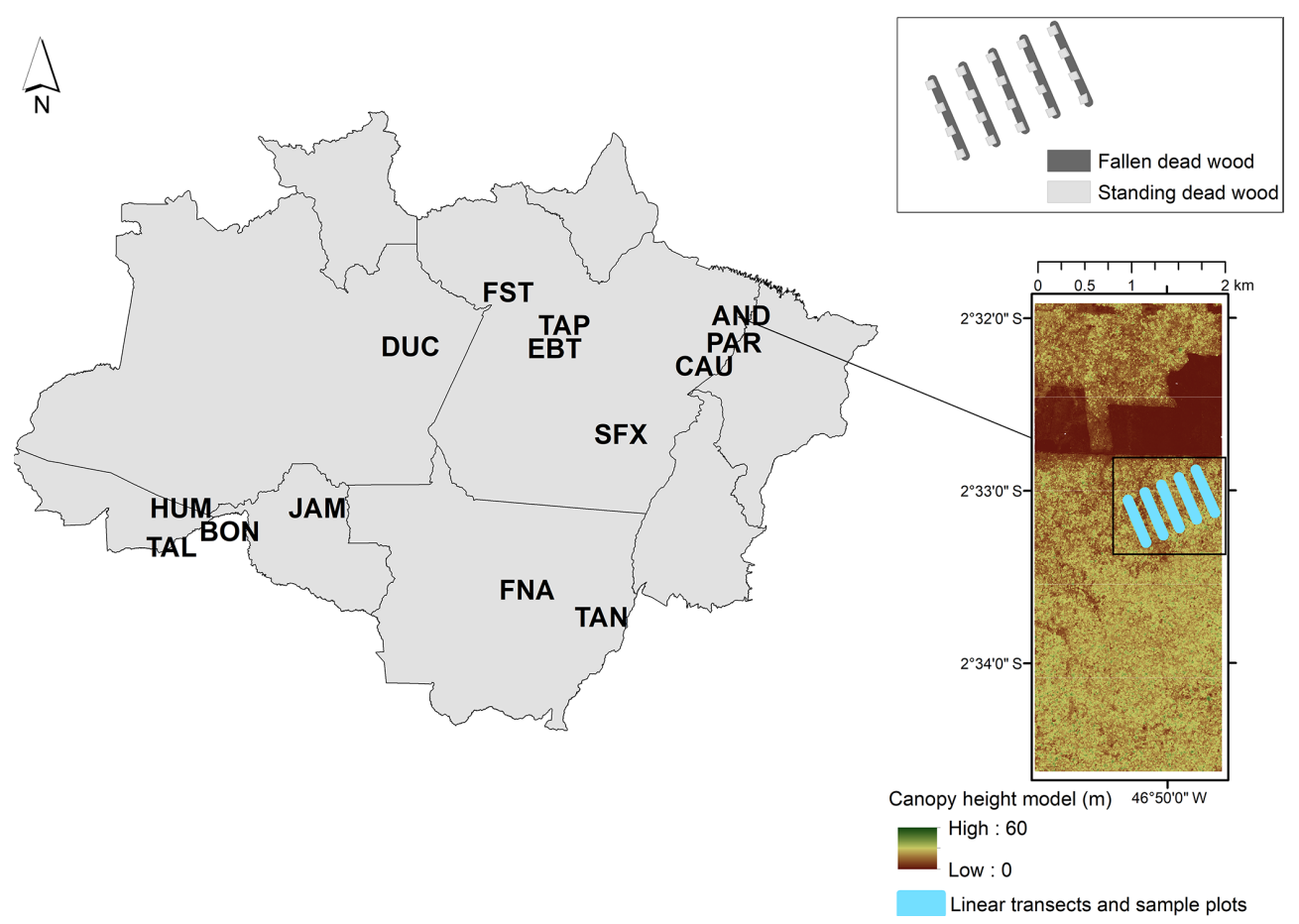

Figure 1. Location of the study sites in the states of Brazilian Legal Amazon. Site codes are shown at approximate locations (see Table 1). The lower inset shows the canopy height model (m) from the AND site as an example of the lidar data covering the field transects for sampling standing and fallen CDW. The upper inset shows the sample design used with line intercept samples to quantify fallen CDW and associated square forest inventory plots for aboveground live and standing CDW. CAU, FST, JAM, TAL, TAN, DUC, and TAP sites were classified as intact; CAU, FST, and JAM sites were classified as reduced-impact logging; BON, PAR, and BET sites were classified as conventional logging; AND, HUM, BET, SFX, TAL, and TAN sites were classified as burned; AND, BON, FNA, and PAR sites were classified as logged and burned; PAR, BET, and SFX sites were classified as secondary; BON, CAU, HUM, SFX, and TAN sites had unclassified transects.

1974). CDW volume was calculated as

$V=\left(\frac{\pi^{2}}{8 L}\right) \sum D^{2}$

where $V$ is the volume of CDW on an area basis $\left(\mathrm{m}^{3} \mathrm{ha}^{-1}\right)$, $D(\mathrm{~cm})$ is the diameter of the wood piece at the line intercept, and $L(\mathrm{~m})$ is the length of the transect used in sampling (Brown, 1974; Keller et al., 2004). Transect lengths varied from 250 up to $1200 \mathrm{~m}$ (16 were $250 \mathrm{~m}, 86$ were $500 \mathrm{~m}$, and 1 was $1200 \mathrm{~m}$ ). Transects were matched with the inventory plots of living and dead trees and within the coverage area of lidar flights (Fig. 1). We used both square plots and belt transects for forest inventory. When the inventory plot shape was square, four inventory plots were established along the CDW line intercept transect (Fig. 1). When the inventory plot was a $20 \mathrm{~m}$ wide belt transect, the line intercept transects for fallen CDW sampling bisected the inventory transect. The distance between the transects was at least $50 \mathrm{~m}$ in order to maintain independence of the samples based on an estimate of maximum tree height (Keller et al., 2004; Palace et al., 2007). A total of 5 to $22 \mathrm{CDW}$ transects were measured at each site.

We classified the wood pieces into five decomposition classes in the field, following published literature (Harmon et al., 1986; Keller et al., 2004), and converted the volume of CDW into mass by multiplying it by the estimated density of the dead wood. At all sites, the wood density values used were: $0.60,0.70,0.58,0.45$, and $0.28 \mathrm{Mg} \mathrm{m}^{-3}$ for decomposition classes $1,2,3,4$, and 5 , respectively $(1=$ intact; $5=$ fragmented woody debris) (Keller et al., 2004).

\subsection{Forest inventory of standing CDW}

Several Sustainable Landscapes partners participated in forest inventory so we had three sampling designs. The standing CDW was assessed by using square inventory plots of $40 \times 40 \mathrm{~m}$ (São Félix do Xingu site only) and $50 \times 50 \mathrm{~m}$ and also long, narrow belt transects of $20 \times 500 \mathrm{~m}$ (Longo et al., 2016). All trees above either $5 \mathrm{~cm}$ or $10 \mathrm{~cm}$ diameter at $1.30 \mathrm{~m}(\mathrm{DBH})$ were tagged and mapped to the nearest $1 \mathrm{~m}$, and diameters were measured using a metric tape with $1 \mathrm{~mm}$ resolution (Longo et al., 2016). We used a handheld clinometer and metric tape for field measurements of tree height (Hunter et al., 2013). Snag volume was estimated as a truncated cone using a taper function (Chambers et al., 2000; Palace et al., 2007) for estimating diameter. Volume was converted to mass using the same classes and densities used for fallen CDW. 


\subsection{Lidar data acquisition and processing}

Geoid Laser Mapping Ltda. (Belo Horizonte, Brazil) acquired small-footprint discrete return lidar (maximum of four returns per pulse) during flights in 2012-2014 (Table 1). In 2012 Geoid used an ALTM 3100 (Optech Inc.), while for data acquired in 2013 and 2014 the company used a similar ALTM Orion M-200 (Optech Inc.). The height of flights averaged $850-900 \mathrm{~m}$ above ground. The field of view was approximately $11^{\circ}$ and the line spacing allowed $65 \%$ overlap between adjacent swaths. Coverage area per site varied from 500 to 1996 ha, with a mean return density of at least 13 returns $\mathrm{m}^{-2}$ (Longo et al., 2016) (Table 1). All transects of fallen CDW and inventory plots were included under the coverage area of lidar flights.

In order to compare lidar metrics to ground-based CDW estimates, we established reference polygons using a buffer of $25 \mathrm{~m}$ on both sides of the fallen CDW transects. The $50 \mathrm{~m}$ total width for our polygons corresponds roughly to the maximum height of a single large tree and was a suitable size to capture canopy gaps. Experiments with narrower transects introduced considerable noise into gap statistics. Wider transects would introduce spatial overlap among samples, thereby compromising the spatial independence of the sample units. Lidar-CDW models were generated and applied at the same resolution $\left(160 \times 160 \mathrm{~m}\right.$, or $\left.\sim 25000 \mathrm{~m}^{2}\right)$.

The lidar point cloud data were processed to produce lidar metrics using the FUSION software (McGaughey, 2014) for all returns (all-return metrics) and $\mathrm{R}$ environment ( $\mathrm{R}$ Core Team, 2017) for calculating the metrics when considering only last laser returns of the forest canopy (last-return metrics) (Table 1). The last-return metrics maximize the penetration through the canopy profile and better reflect understory structure (Réjou-Méchain et al., 2015). A digital terrain model (DTM) for each site was supplied by our lidar vendor based on Terrascan software. We previously compared the vendor-provided DTMs with the NASA G-LiHT algorithms (Cook et al., 2013) and field geodesic GNSS measurements and found that they generally agreed to within less than $1 \mathrm{~m}$ vertical height (RMSE) at a $1 \mathrm{~m}$ horizontal resolution (Leitold et al., 2015). We normalized all vegetation returns to height above ground by subtracting the height of the DTM at $1 \mathrm{~m}$ resolution. We subsampled lidar point cloud data by clipping the field plot polygons with the DTM-normalized vegetation returns.

Along with traditional lidar metrics, we also mapped canopy gaps and derived four gap metrics. Forest canopies less than or equal to $10 \mathrm{~m}$ in height with a minimum area of $10 \mathrm{~m}^{2}$ in the $1 \mathrm{~m}$ resolution canopy height model were considered gaps (Hunter et al., 2015). Gap areas in each plot were summarized based on gap area $\left(\mathrm{m}^{2} \mathrm{ha}^{-1}\right)$, mean gap size $\left(\mathrm{m}^{2}\right)$, standard deviation of gap size assuming a lognormal distribution $\left(\mathrm{m}^{2}\right)$, and gap count $\left(\right.$ gaps ha $\left.^{-1}\right)$ (Table 1).

\subsection{Forest disturbance history}

Based on visual interpretation of Landsat images, we found 30 transects in intact forests, 30 in logged forests, 17 in burned forests, 14 in logged and burned forests, and 4 in secondary forests (regeneration following complete clearing for agriculture or pasture). For modeling, transects classified as logged and burned were merged into the burned class. Eight transects were not classified because we lacked cloud-free images (Fig. 1 and Table 1). Where degradation was identified, the number of events ranged from one (accounting for $70 \%$ of the transects), up to a maximum of five in a case where a logging event was followed by four events of burning. The median age since the last disturbance was 4 years, ranging from 0.5 (recently logged) up to 23 years following burning.

\subsection{Statistical models}

We developed multivariate linear and nonlinear models relating lidar metrics from a single date acquisition period to CDW. For all models, we summed the fallen CDW from each transect and the mean value of standing CDW from the associated forest inventory belt transect or four square plots (Fig. 1), normalized for the area sampled. Through our exploration of the data, we found no significant general model that applied across all forests and disturbance types. Therefore, we stratified the sites into three classes: intact, logged, and burned. Logged sites included both conventional and reduced-impact logging, and burned sites included forests that had been logged and burned. We designated models that used only lidar point cloud metrics as independent variables for a given forest class as lidar-only models. We also developed historical models that included site identifier or additional land use history information beyond forest class. The land use history information derived from Landsat time series included the number of disturbance events and the years since the last disturbance. Detailed information about all Landsat and lidar-derived metrics are found in Table 2. The approaches for model selection for lidar-only and historical models are described separately below.

For lidar-only models, we used the subset selection approach to identify the simplest and most informative combination of variables (Andersen et al., 2014; Miller, 1984). We excluded highly correlated variables $(r \geq 0.80)$ and calculated the variation inflation factor (VIF) in the final models to test for multicollinearity.

For the historical models, we used the framework proposed by Bolker et al. (2009) for input variable selection. We first selected potential covariates (both Landsat and lidarderived) with expected theoretical relations with CDW. For intact forests, we selected the canopy relief ratio as a measure of canopy structure and site factor for aggregating sitespecific differences. Previous studies in intact forests suggested differences in CDW stocks, as well as the underly- 
Table 2. Landsat-derived variables and lidar metrics used as potential covariates for modeling CDW in intact and degraded Amazonian forests.

\begin{tabular}{|c|c|}
\hline Landsat & Description \\
\hline Degradation class & Status of degradation such as intact, logged, burned, and burned after logging. \\
\hline $\begin{array}{l}\text { Age since the last } \\
\text { degradation event }\end{array}$ & The age (years) since the last degradation event. \\
\hline Number of degradation events & Number of events of logging or burning. \\
\hline \multicolumn{2}{|l|}{ Lidar } \\
\hline Percentiles & $\begin{array}{l}\text { Percentiles } 1,5,10,20,30,40,50,60,70,80,90 \text { and } 99 \text { of } \\
\text { the return distribution. }\end{array}$ \\
\hline $\begin{array}{l}\text { Return fraction among height } \\
\text { intervals }\end{array}$ & $\begin{array}{l}\text { Fractions of returns among predetermined height intervals (e.g., from } 0 \text { to } 1 \mathrm{~m} \text { ) } \\
\text { or above a predetermined height (e.g., above } 20 \mathrm{~m} \text { ). }\end{array}$ \\
\hline Gap metrics & $\begin{array}{l}\text { Mean gap size }\left(\mathrm{m}^{2}\right) \text {, standard deviation of gap size, standard deviation of gap } \\
\text { size assuming a log-normal distribution, gap area }\left(\mathrm{m}^{2} \mathrm{ha}^{-1}\right) \text {, and gap count } \\
\left(\text { gaps ha } \mathrm{a}^{-1}\right) \text {. }\end{array}$ \\
\hline $\begin{array}{l}\text { Canopy relief ratio } \\
\text { (Parker and Russ, 2004) }\end{array}$ & $\begin{array}{l}\text { A quantitative descriptor of the relative shape of the canopy } \\
\text { defined as } \\
\text { ((mean height-min height) / (max height-m.in height) })\end{array}$ \\
\hline Moments of return distribution & Mean, median, variance, skewness, and kurtosis \\
\hline $\begin{array}{l}\text { L-moments of return } \\
\text { distribution }\end{array}$ & $\begin{array}{l}\text { L-moments (first, second, third, and fourth) are linear combinations of ordered } \\
\text { data values (elevation returns) described by Hosking (1990), analogous } \\
\text { to traditional moments. }\end{array}$ \\
\hline
\end{tabular}

ing mechanisms in the CDW input (Rice et al., 2004; Pyle et al., 2008). For logged forests, we selected age since the last disturbance because CDW diminishes with time because of decomposition (Chambers et al., 2000). We also selected gap area because tree mortality and CDW stocks were closely related to gap area in intact forests at Tapajós National Forest, Pará (Espírito-Santo et al., 2013). For burned forests, we selected the number of fire events, in addition to age and gap area. A previous study conducted in Paragominas municipality, Pará, and Alta Floresta, Mato Grosso, showed the gradual increase in CDW stocks from one to three fire events (Cochrane et al., 1999). In both logged and burned forests we included a measure of forest canopy height correlated to live aboveground biomass (Longo et al., 2016) because aboveground live biomass is significantly correlated with CDW across the Amazon (Chao et al., 2008). After choosing the covariates for logged and burned forests, we fit a full model using ordinary least squares and then performed a backward selection of the best predictors and their combinations using the Bayesian information criterion (BIC). For intact forests, we used a mixed-effect model including site identifier as both a fixed and random variable (Pinheiro and Bates, 2000).

We $\log$ transformed (natural $\log$ ) the response variables when necessary for improved model prediction and error distribution assumptions. We then back-transformed using the Baskerville bias corrector $\left(\exp \left(\sigma_{\varepsilon}^{2} / 2\right)\right)$ for model assessment
(Baskerville, 1972). We used adjusted $R^{2}$, relative bias (bias, in \%; mean error divided by observed mean), and relative root mean square error (RMSE, in \%; square root of the mean squared error divided by the observed mean) as goodness-offit measures for comparison with other studies on lidar-CDW models (Pesonen et al., 2008). We did not calculate adjusted $R^{2}$ for the linear mixed-effect model because of the difference in accounting for the number of parameters in both fixed and random terms, compared to the ordinary least squares method (Bolker et al., 2009).

\section{Results}

\subsection{Field sample CDW variability}

The overall mean ( \pm standard deviation) total CDW (including fallen and standing dead wood) stock grouped by site was $50.6( \pm 17.7) \mathrm{Mg} \mathrm{ha}^{-1}$. Individual site averages ranged from 21.8 to $93.0 \mathrm{Mgha}^{-1}$ (Table 3). When grouped by degradation level and site, average total CDW was lower for burned forests $\left(40.4 \pm 29.7 \mathrm{Mg} \mathrm{ha}^{-1}\right)$ than logged forests $\left(70.9 \pm 19.9 \mathrm{Mg} \mathrm{ha}^{-1}\right)$. In comparison, intact forests grouped by site had an average total CDW of $42.4( \pm 19.7) \mathrm{Mg} \mathrm{ha}^{-1}$. Logged forests had the largest CDW stocks with an average of $70.9 \pm 19.9 \mathrm{Mgha}^{-1}$ and recorded the largest CDW stock $\left(150 \mathrm{Mg} \mathrm{ha}^{-1}\right)$ in a single transect in FST, where log- 
Table 3. CDW (mean and standard deviation) by degradation level and site. AGB, standing CDW, fallen CDW, and total CDW are in $\mathrm{Mg}$ ha ${ }^{-1}$.

\begin{tabular}{|c|c|c|c|c|c|c|c|c|c|c|}
\hline \multirow[t]{2}{*}{ Site } & \multirow[t]{2}{*}{ Degradation level } & \multirow[t]{2}{*}{$n$} & \multicolumn{2}{|c|}{ AGB } & \multicolumn{2}{|c|}{ Standing CDW } & \multicolumn{2}{|c|}{ Fallen CDW } & \multirow[t]{2}{*}{ Total CDW } & \multirow[t]{2}{*}{ CDW/AGB } \\
\hline & & & mean & SD & mean & SD & mean & SD & & \\
\hline \multirow[t]{2}{*}{ AND } & BRN & 4 & 184.0 & 21.9 & 17.7 & 5.0 & 40.6 & 10.4 & 58.2 & 0.3 \\
\hline & $\mathrm{CVL}+\mathrm{BRN}$ & 1 & 106.4 & - & 21.7 & - & 54.1 & - & 75.8 & 0.7 \\
\hline \multirow[t]{3}{*}{$\mathrm{BON}$} & CVL & 2 & 211.9 & 49.9 & 5.2 & 6.1 & 14.7 & 4.8 & 19.9 & 0.1 \\
\hline & $\mathrm{CVL}+\mathrm{BRN}$ & 3 & 166.2 & 10.6 & 5.7 & 3.8 & 38.8 & 9.3 & 44.5 & 0.3 \\
\hline & UKN & 1 & 342.7 & - & 0.7 & - & 7.2 & - & 7.9 & 0.0 \\
\hline \multirow[t]{3}{*}{ CAU } & INT & 4 & 410.6 & 13.7 & 7.1 & 5.3 & 26.1 & 10.4 & 33.2 & 0.1 \\
\hline & RIL & 16 & 351.7 & 58.8 & 12.6 & 6.5 & 47.8 & 24.2 & 60.3 & 0.2 \\
\hline & $\mathrm{UKN}$ & 2 & 489.7 & 63.0 & 15.6 & 5.6 & 22.1 & 6.3 & 37.7 & 0.1 \\
\hline DUC & INT & 10 & 325.3 & 129.6 & 9.2 & 6.0 & 48.5 & 15.7 & 57.6 & 0.2 \\
\hline FNA & $\mathrm{CVL}+\mathrm{BRN}$ & 5 & 3.8 & 4.7 & 18.3 & 4.7 & 29.3 & 6.4 & 47.6 & 12.6 \\
\hline \multirow[t]{2}{*}{ FST } & INT & 1 & 416.9 & - & 25.7 & - & 37.1 & - & 62.9 & 0.2 \\
\hline & RIL & 4 & 345.6 & 66.8 & 16.7 & 8.7 & 83.8 & 41.6 & 100.5 & 0.3 \\
\hline \multirow[t]{2}{*}{ HUM } & BRN & 3 & 194.6 & 44.7 & 2.5 & 0.8 & 10.5 & 5.9 & 13.1 & 0.1 \\
\hline & UKN & 3 & 192.7 & 97.6 & 5.1 & 3.7 & 49.4 & 12.5 & 54.5 & 0.3 \\
\hline \multirow[t]{2}{*}{ JAM } & INT & 3 & 264.2 & 45.0 & 16.8 & 1.2 & 19.7 & 10.6 & 36.5 & 0.1 \\
\hline & RIL & 3 & 228.1 & 78.1 & 20.3 & 4.0 & 40.2 & 8.2 & 60.4 & 0.3 \\
\hline \multirow[t]{3}{*}{ PAR } & CVL & 4 & 151.6 & 48.6 & 9.5 & 2.5 & 37.9 & 25.1 & 47.4 & 0.3 \\
\hline & $\mathrm{CVL}+\mathrm{BRN}$ & 5 & 81.2 & 22.7 & 17.8 & 8.0 & 55.3 & 18.9 & 73.1 & 0.9 \\
\hline & SEC & 1 & 109.6 & - & 8.2 & - & 35.7 & - & 43.8 & 0.4 \\
\hline \multirow[t]{3}{*}{ EBT } & CVL & 1 & 155.1 & - & 13.5 & - & 53.8 & - & 67.3 & 0.4 \\
\hline & $\mathrm{BRN}$ & 1 & 129.3 & - & 30.2 & - & 62.5 & - & 92.7 & 0.7 \\
\hline & SEC & 2 & 107.4 & 17.4 & 5.8 & 0.9 & 32.6 & 12.5 & 38.4 & 0.4 \\
\hline \multirow[t]{3}{*}{ SFX } & BRN & 4 & 199.4 & 71.6 & 7.6 & 3.2 & 11.4 & 4.1 & 19.0 & 0.1 \\
\hline & UKN & 1 & 155.5 & - & 30.1 & - & 13.0 & - & 43.1 & 0.3 \\
\hline & SEC & 1 & 145.0 & - & 34.1 & - & 17.9 & - & 52.0 & 0.4 \\
\hline \multirow[t]{2}{*}{ TAL } & INT & 1 & 150.7 & - & 6.2 & - & 12.7 & - & 18.9 & 0.1 \\
\hline & $\mathrm{BRN}$ & 2 & 138.5 & 5.5 & 12.0 & 1.5 & 42.1 & 19.8 & 54.1 & 0.4 \\
\hline \multirow[t]{3}{*}{ TAN } & INT & 2 & 167.1 & 38.9 & 10.4 & 1.8 & 11.3 & 0.8 & 21.6 & 0.1 \\
\hline & BRN & 3 & 160.1 & 26.0 & 19.9 & 9.0 & 12.7 & 6.0 & 32.5 & 0.2 \\
\hline & $\mathrm{UKN}$ & 1 & 114.1 & - & 21.3 & - & 11.3 & - & 32.5 & 0.3 \\
\hline TAP & INT & 9 & 247.7 & 101.4 & 6.6 & 5.2 & 59.6 & 21.9 & 66.2 & 0.3 \\
\hline
\end{tabular}

ging had occurred less than 6 months prior to the data collection. The mean total CDW stock was $21.0( \pm 2.0) \mathrm{Mg} \mathrm{ha}^{-1}$ in TAN intact transects - less than DUC and TAP intact transects. The mean total CDW stock was $57.6( \pm 15.0)$ and $66.2( \pm 20.0) \mathrm{Mg} \mathrm{ha}^{-1}$ in DUC and TAP, respectively.

\subsection{Modeling scenarios}

The best lidar-based predictor of total CDW for transects classified as intact was the 75 th percentile of last returns (m) (Fig. 2a). The gap area $\left(\mathrm{m}^{2} \mathrm{ha}^{-1}\right)$ was the best predictor of total coarse wood debris for transects classified as logged
(Fig. 2b). For burned forests, total CDW was inversely related to the return fraction above $30 \mathrm{~m}$ (Fig. 2c).

Models for total CDW in the lidar-only scenarios generally performed well (Table 4; Fig. 3). Relative RMSE ranged from $33 \%$ for total CDW in logged forest to up to $36 \%$ in burned forest (Table 4). The predictions depended, in part, on last-return metrics for intact forest classes and notably, gap area for the logged class. The 1st and 10th percentile of all returns, as well as the mode of all return heights, were also important for predictions in the logged and burned classes. Models that separately considered fallen and standing CDW 

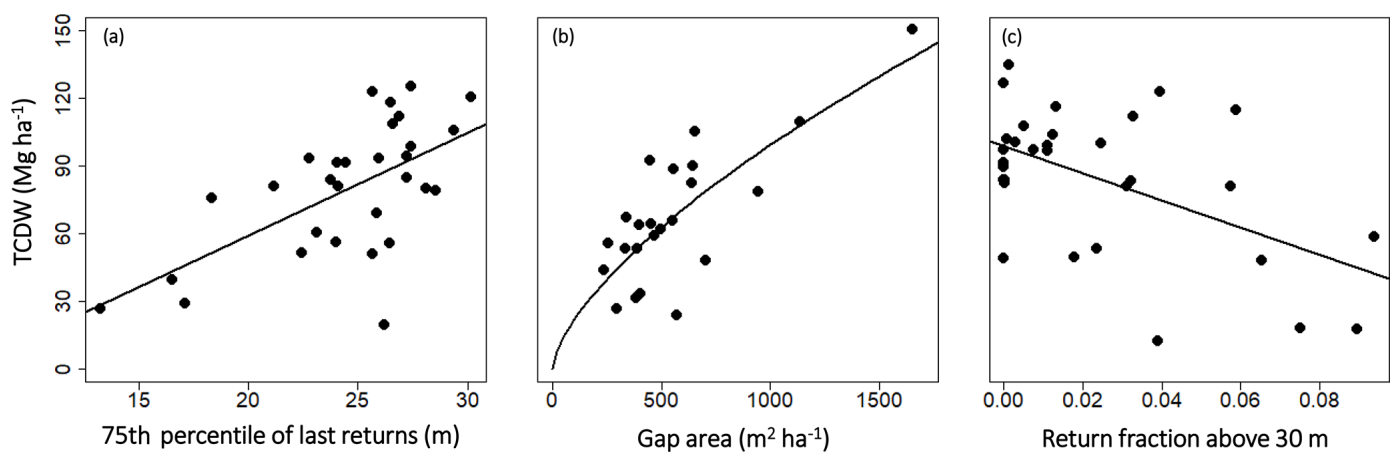

Figure 2. Relationship between total CDW (TCDW) and the best single lidar-based predictor variable of TCDW: (a) the 75th percentile of last returns $(\mathrm{m})(n=30)$ for transects classified as intact; (b) gap area $\left(\mathrm{m}^{2} \mathrm{ha}^{-1}\right)(n=23)$ for reduced-impact logging transects; (c) return fraction above $30 \mathrm{~m}$ (last returns) for transects classified as burned $(n=30)$. (a) $\ln (\mathrm{TCDW})=1.96+0.0875$ th percentile of last returns. $P<0.01$; adjusted $R^{2}: 0.36$. (b) TCDW $=1.04$ gap area ${ }^{0.66} . P<0.01$; adjusted $R^{2}: 0.57$. (c) $\ln (\mathrm{TCDW})=-3.97-11.95$ return fraction above $30 \mathrm{~m}$. $P<0.01$; adjusted $R^{2}: 0.25$.

components produced poorer fits than models of total CDW (Table B2).

The inclusion of disturbance history and site identifier in the historical models led to modest improvements in the quality of prediction for total CDW in intact forest, a very small gain (1\% decrease in RMSE) for logged forests, and a poorer fit ( $9 \%$ increase in RMSE) for burned forest (Table 5). The historical model for intact forest included two site-related variables in the mixed model, a site factor, and a random slope for the canopy relief ratio at each site. Historical models that separately fit fallen and standing CDW components produced poorer results than for total CDW (Table B3).

Although the lidar-only models had relatively good performance measured by adjusted $R^{2}$ and RMSE, we also examined whether the models were biased. In general, we found no evidence of biases (Figs. 4 and 5) or heteroskedasticity in the model residuals (Fig. 5). Measured by mean relative bias, the model for burned forests had the poorest performance among the lidar-only models with a value of $-3 \%$. The mean relative bias for the historical scenario was $0.0 \%$, $0.0 \%$, and $-3.9 \%$ for the intact, logged, and burned forests, respectively (Table 5).

In the lidar-only group models, some of the lidar metrics chosen by subset selection reflected site history. For example, in the intact forests the total gap area decreased exponentially with an increasing return fraction between 0 and $1 \mathrm{~m}$ height. In the burned forests, the return fraction above $30 \mathrm{~m}$ height decreased significantly with increasing number of fires. In the logged forests the first percentile tended to increase with the age since the last logging event, indicating the recovery of the forest from the logging event, a control over the decomposition of CDW.

\subsection{Landscape level prediction of CDW}

For comparison to published field surveys, we applied the lidar-only models over the entire lidar scenes $(\sim 1000$ ha each) for three intact sites, one logged site, and one burned site at a $166 \mathrm{~m}$ resolution (Fig. 5). For TAP, the landscape level predicted mean was $51.3 \pm 18.8$ (standard deviation) $\mathrm{Mg} \mathrm{ha}^{-1}$ and the range was $15-91 \mathrm{Mg} \mathrm{ha}^{-1}$ after excluding one outlier pixel located on the edge of the lidar scene with $146.0 \mathrm{Mg} \mathrm{ha}^{-1}$ of CDW (Fig. 5a). For DUC, the landscape mean CDW was $41.6 \pm 5.0 \mathrm{Mg} \mathrm{ha}^{-1}$ and the range was $22-61 \mathrm{Mg} \mathrm{ha}^{-1}$ (Fig. 5b). For the Fazenda Tanguro intact site (TAN), the landscape mean CDW was $21.0 \pm$ 2.0 $\mathrm{Mg} \mathrm{ha}^{-1}$ (Fig. 5c).

For the Fazenda Cauaxi logged site (CAU), the landscape mean CDW was $84.6 \pm 27.5 \mathrm{Mg} \mathrm{ha}^{-1}$ and the landscape mean for intact forests at the same site was $54.2 \pm$ 8.8 (Fig. 5d) $\mathrm{Mgha}^{-1}$. At this site, in the logged forests there were extremely high predicted values ranging from $161.0 \mathrm{Mg} \mathrm{ha}^{-1}$ to up to $200.0 \mathrm{Mg} \mathrm{ha}^{-1}$ (Fig. $5 \mathrm{~d}$ ). The occurrence of gap areas out of the range used for calibration contributed to the prediction of those outliers. Finally, for the burned site in Fazenda Tanguro the predicted landscape level mean of $46.5 \mathrm{Mg} \mathrm{ha}^{-1}$ was about twice the mean for undisturbed forest at this site (Fig. 5c).

\section{Discussion}

\subsection{Lidar models and controls on CDW}

Necromass stocks in intact forests are controlled by the balance between inputs from tree and branch fall and loss from CDW decay (Chao et al., 2009; Palace et al., 2008). The slight increase in the performance of the model for intact forests in the historical scenario (Tables 4 and 5), compared to the lidar-only model, highlights that differences in site- 

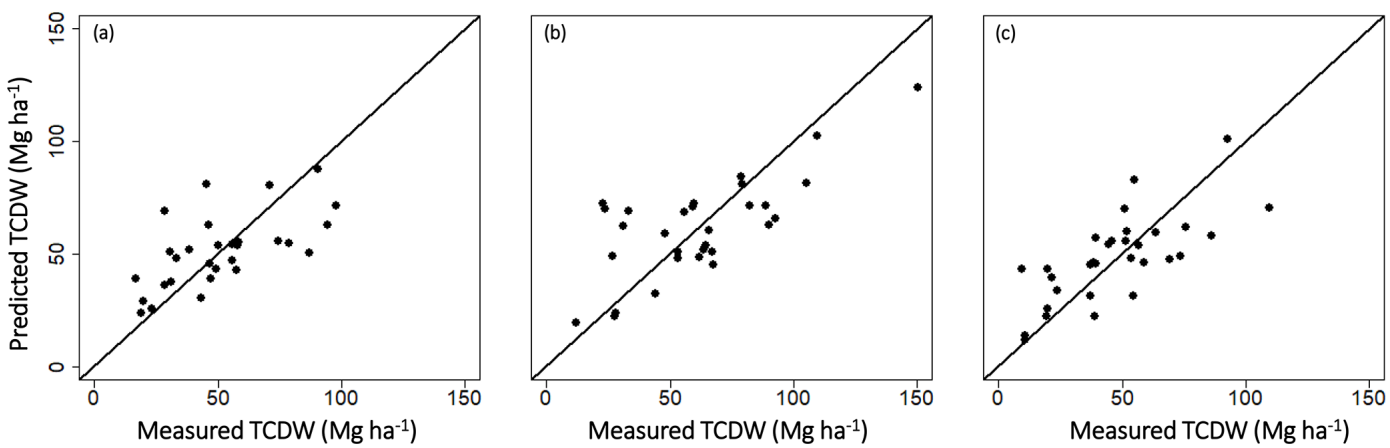

Figure 3. Measured values of total CDW (TCDW) versus values predicted by the models for lidar-only scenarios for forests classified as (a) intact (adjusted $R^{2}: 0.44$; RMSE (\%): 35.1), (b) logged (adjusted $R^{2}: 0.50 ;$ RMSE (\%): 33.0), and (c) burned (adjusted $R^{2}: 0.51 ;$ RMSE (\%): 36.0).

Table 4. Equations, adjusted $R^{2}$, mean relative bias (\%), and relative root mean square error (RMSE in \%) of the lidar-only scenario for predicting CDW in intact and degraded forests using lidar variables. $r f_{01 \mathrm{~m}}$ is return fractions between 0 and $1 \mathrm{~m}$ height of the last returns; P75 last is the 75th percentile of last returns in meters; gap area is gap area in $\mathrm{m}^{2} \mathrm{ha}^{-1}$; Mode $\mathrm{all}_{\text {all }}$ is mode of all returns in meters. P05 all is the fifth percentile of all returns in meters; $r f_{\text {above }} 30 \mathrm{~m}$ is return fraction above $30 \mathrm{~m}$ of all returns. EN is residual following a normal distribution with $\mu$ and $\sigma$.

\begin{tabular}{|c|c|c|c|c|}
\hline Land use & Equation & Adjusted $R^{2}$ & Bias (\%) & $\operatorname{RMSE}(\%)$ \\
\hline Intact & $\begin{array}{l}\ln \mathrm{TCWD}=1.00(0.33) r f 01 \mathrm{~m}^{-0.07(0.03)} \mathrm{P} 75_{\text {last }} 0.34(0.11)+ \\
\mathrm{EN}(\mu=0, \quad \sigma=0.36)\end{array}$ & 0.44 & -0.41 & 35.1 \\
\hline Logged & $\begin{array}{l}\text { TCWD }=-48.63(22.27)+0.07(0.01) \text { gap area }+ \\
2.40(0.63) \text { Mode }_{\text {all }}+190.98(83.26) \mathrm{P} 01_{\text {all }}+\mathrm{EN}(\mu=0, \quad \sigma= \\
22.02)\end{array}$ & 0.50 & 0.00 & 33.0 \\
\hline Burned & $\begin{array}{l}\ln \mathrm{TCWD}=3.88(0.14)+1.05(0.27) \mathrm{P} 05_{\mathrm{all}}- \\
0.03(0.01) \mathrm{Mode}_{\text {all }}-11.91(2.05) r f_{\text {above } 30 \mathrm{~m}}+\mathrm{EN}(\mu= \\
0, \quad \sigma=0.45)\end{array}$ & 0.51 & -3.00 & 36.0 \\
\hline
\end{tabular}

specific characteristics controlling the input and decay of CDW might be important for predicting CDW in Amazonian forests. For the lidar-only scenario we found an increase in total CDW in the intact forests with increasing values of the 75th percentile of last returns, a metric related to the overall increase in both canopy and understory height and a correlate of total biomass. Our results are consistent with Chao et al. (2009), who also found a weak correlation between total CDW and live biomass, whereas Martins et al. (2015) related CDW stocks to mean biomass per tree.

Logging and fire differentially affected CDW in Amazonian degraded forests. Fire events tended to produce more standing CDW than fallen, whereas most of the total CDW in logged forest was fallen. The ratio between standing and fallen CDW is suggestive of the predominant mode of tree death. The most pronounced difference between logging and fire was the effect of gap area on the amount of CDW (Fig. 2). A significant amount of CDW is associated with gap creation in intact Amazonian forests (Espírito-Santo et al., 2014a, b), and our models for logging confirm a strong relation between gap area and CDW. Considering both age since the last dis- turbance and number of degradation events in the historical models, gap area was still positively related to CDW stocks in logged forests, whereas the opposite trend was found in burned forests. For example, for a single degradation event of an age of 1 year in the historical models, the increase in gap area from $300 \mathrm{~m}^{2} \mathrm{ha}^{-1}$ to up to $1000 \mathrm{~m}^{2} \mathrm{ha}^{-1}$ led to an increase of $0.06 \mathrm{Mg}$ of CDW per square meter of gap in logged forests and a decrease of $0.012 \mathrm{Mg}$ of CDW per square meter of gap in burned forests. For additional fire events, there are compensatory effects controlling CDW stocks. Fires lead to mortality, thereby increasing stocks but also consume existing CDW at the time of the fire. The opposite signs of the parameters for gap area and the number of events reflect these opposing controls.

\subsection{Comparisons to other lidar-related models}

Two classes of models have been used for CDW estimation using lidar: (1) area-based models estimate CDW indirectly based on lidar metrics calibrated with data from forest inventory plots (Martinuzzi et al., 2009; Pesonen et al., 2008), and (2) individual-based models identify standing dead trees 

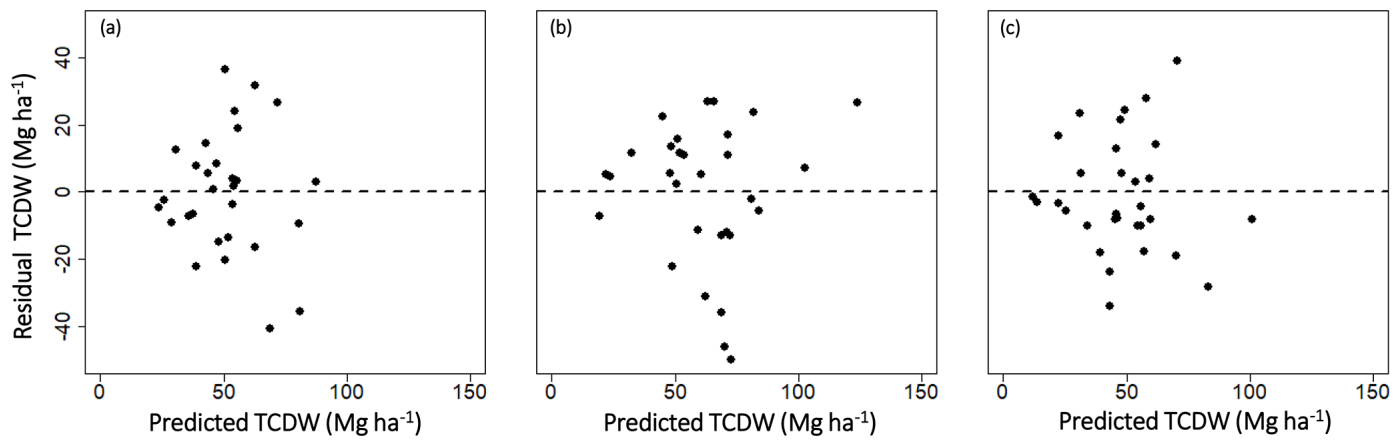

Figure 4. Residuals versus predicted values of total CDW (TCDW) by the models for lidar-only scenario for forests classified as (a) intact (mean bias (\%): -0.41), (b) logged (mean bias (\%): 0.00) and (c) burned (mean bias (\%): -3.00).

(a) TAP site
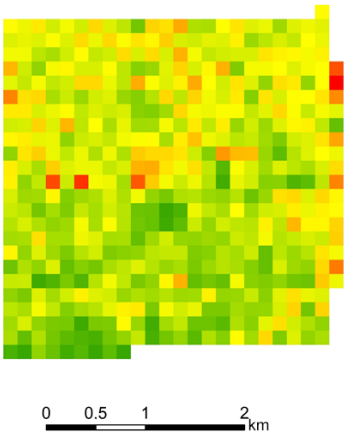

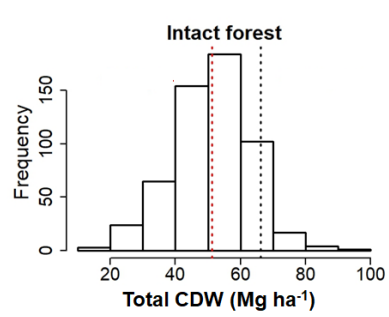

Total CDW $($ Mg ha-1)
High : 100

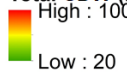

(b) DUC site

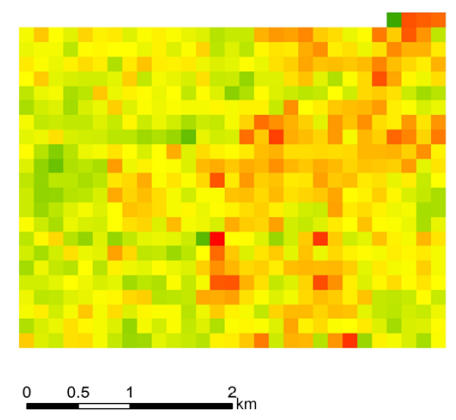

(d) CAU site

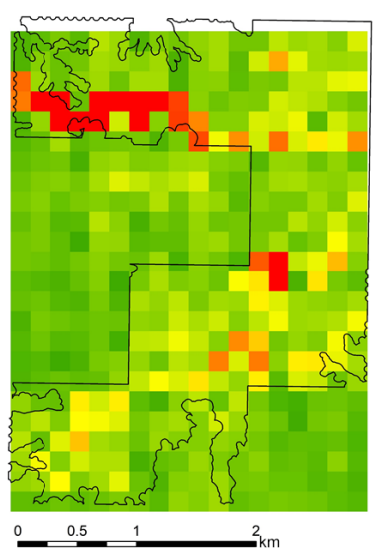

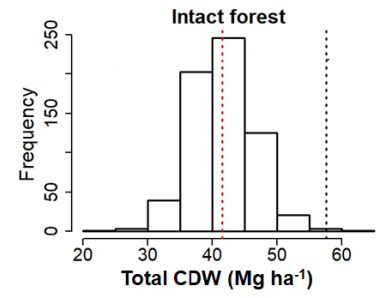

Total CDW $\left(\right.$ Mg ha $\left.^{-1}\right)$

Low : 22

(c) TAN site

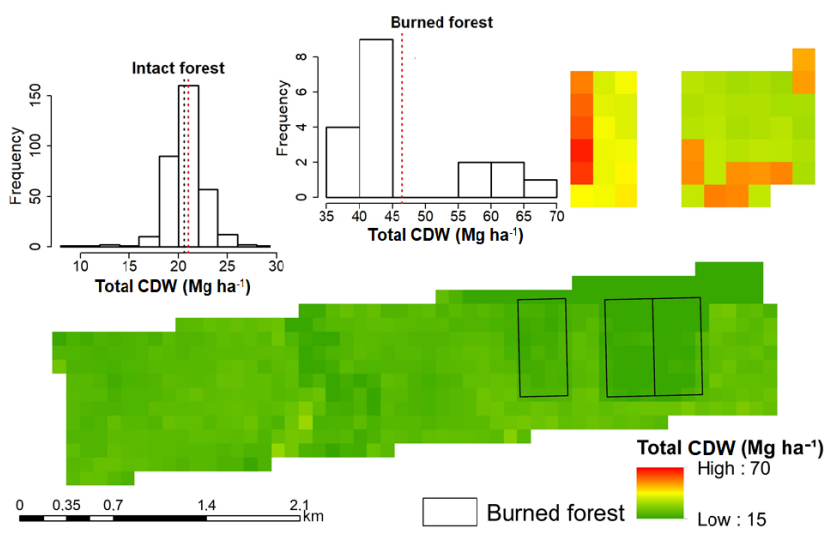

Figure 5. Wall-to-wall maps and histograms of total CDW predicted by lidar-only models at landscape level (166 m resolution). For intact forest at the Tapajós National Forest (a) the predicted mean was $51.3 \pm 11.8 \mathrm{Mg} \mathrm{ha}^{-1}$ (red dotted line) and the field-based mean from our database was $66.2 \pm 20.0 \mathrm{Mg} \mathrm{ha}^{-1}$ (black dotted line). For intact forest at Reserva Adolpho Ducke (b) the predicted mean was $41.6 \pm$ $5.0 \mathrm{Mg} \mathrm{ha}^{-1}$ and the field-based mean from our database was $57.6 \pm 20.0 \mathrm{Mg} \mathrm{ha}^{-1}$. For intact forests at Fazenda Tanguro (c) the predicted mean was $21.0 \pm 2.0 \mathrm{Mg} \mathrm{ha}^{-1}$ and the field-based mean was $20.6 \pm 1.8 \mathrm{Mg} \mathrm{ha}^{-1}$. For burned forests (highlighted as a second panel in the CDW map) the predicted mean was $46.5 \pm 9.8 \mathrm{Mg} \mathrm{ha}^{-1}$ and the field-based mean was $32.5 \pm 6.0 \mathrm{Mg} \mathrm{ha}^{-1}$. For intact forests at Fazenda Cauaxi (d) the predicted mean was $54.2 \pm 8.8 \mathrm{Mg} \mathrm{ha}^{-1}$ and the field-based mean was $33.2 \pm 10.0 \mathrm{Mg} \mathrm{ha}^{-1}$. For logged forests the predicted mean was $84.6 \pm 27.5 \mathrm{Mg} \mathrm{ha}^{-1}$ and the field-based mean was $60.3 \pm 24.0 \mathrm{Mg} \mathrm{ha}^{-1}$; high CDW areas in the northern portion of the image are associated with the main road through the logging site. Red dotted lines indicate the predicted mean by the lidar-only model, and black dotted lines indicate the field-based mean from the sample transects and inventory plots. 
Table 5. Equations, adjusted $R^{2}$, mean relative bias (\%), and relative root mean square error (RMSE in \%) of the historical scenario for predicting CDW in intact and degraded forests using Landsat and lidar variables. The parameters of the mixed-effect model for intact forests are shown in Table B1 in the Appendix. Age is the number of years since the last disturbance event. Gap area is total gap area in square meters per hectare. P05 last is the fifth percentile of the last returns. NumberEvent is the count of degradation events. CRR is canopy relief ratio. EN is the residual following a normal distribution with $\mu$ and $\sigma$. Estimated parameters by each site (fixed effect) are found in Table B1.

\begin{tabular}{|c|c|c|c|c|}
\hline Land use & Equation & Adjusted $R^{2}$ & $\begin{array}{c}\text { Bias } \\
(\%)\end{array}$ & $\begin{array}{r}\text { RMSE } \\
(\%)\end{array}$ \\
\hline \multirow[t]{2}{*}{ Intact } & Fixed effect variables, random slope by site & & & \\
\hline & $\begin{array}{l}\text { TCWD }=3.40+\text { Site Factor }+119.72(126.18) \mathrm{CRR}+ \\
\text { CRR by site }+\mathrm{EN}(\mu=0, \quad \sigma=14.14)\end{array}$ & - & 0.00 & 31.3 \\
\hline Logged & $\begin{array}{l}\text { TCWD }=26.29(13.71)-5.45(1.62) \text { Age }+ \\
0.06(0.01) \text { Gap Area }+65.50(20.71) \mathrm{P} 5_{\text {last }}+\mathrm{EN}(\mu= \\
0, \quad \sigma=20.43)\end{array}$ & 0.52 & 0.00 & 32.0 \\
\hline Burned & $\begin{array}{l}\ln \mathrm{TCWD}=3.43(0.24)-0.05(0.01) \text { Age }- \\
0.0003(0.00) \text { Gap Area }+0.53(0.10) \text { Number Event }+ \\
\mathrm{EN}(\mu=0, \quad \sigma=0.46)\end{array}$ & 0.46 & -3.9 & 45.0 \\
\hline
\end{tabular}

(Casas et al., 2016) and downed trees on the ground (Blanchard et al., 2011; Polewski et al., 2015). The individualbased approach is generally more appropriate for identifying and estimating volume or basal area of standing and fallen dead trees in more open canopies and a lack of dense vegetation, compared to the dense tropical forests that we studied (Blanchard et al., 2011). We employed only area-based models, and so we will compare our results only to other results of this category.

In the area-based approach, CDW metrics may reflect underlying mechanisms generating CDW. For example, lidar metrics related to gaps such as intensity of returns accumulated closer to the ground and standard deviation of returns were both included as predictors of fallen CDW volume in a boreal forest in North Karelia, Finland (Pesonen et al., 2008). In the boreal forest, the model for fallen coarse woody volume had a relative RMSE of $51.6 \%$ and is similar to the performance of the model for burned sites in our historical scenario. As we found, in the area-based approach, models for predicting standing necromass are poorer than the models for fallen dead wood, which is similar to findings in boreal forest (Pesonen et al., 2008). The boreal forest model for standing dead tree volume had a relative RMSE of $78.8 \%$ (Pesonen et al., 2008).

Our landscape level means and ranges at the four intact sites, as well as at the logged and burned site, were similar to published field surveys. Hayek et al. (2018) found $61.0 \pm 14.8 \mathrm{Mg} \mathrm{ha}^{-1}$ of CDW stock in the Tapajós National Forest $\left(51.3 \pm 18.8 \mathrm{Mg} \mathrm{ha}^{-1}\right.$ from this study). Martins et al. (2015) reported a range of $6.7-72.9 \mathrm{Mgha}^{-1}$ of CDW stock in the Reserva Adolpho Ducke (mean of 41.6 and range of $22-60 \mathrm{Mg} \mathrm{ha}^{-1}$ from this study). Keller et al. (2004) found an average of $55.2 \pm 4.7$ and $74.7 \pm 0.6 \mathrm{Mg} \mathrm{ha}^{-1}$ of fallen
CDW in an intact and logged site, respectively, at Fazenda Cauaxi (54.2 \pm 8.8 and $84.6 \pm 27.5 \mathrm{Mg} \mathrm{ha}^{-1}$ from this study).

Preliminary analysis of wall-to-wall maps created with our lidar-only models alongside the histograms (Fig. 5) revealed a unique potential for explaining spatial patterns of CDW in intact forests and assessing the effect of degradation on CDW stocks. The total CDW stock was higher in eastern and central Amazonian intact forests than in the southern intact forests (Chao et al., 2009). In addition, the spatial pattern and the dispersion of CDW distribution at the TAP and DUC sites illuminate the mechanisms controlling CDW at landscape level. First, the CDW stocks at DUC are strongly related to topography (Fig. A1 in Appendix). At the DUC site, there is a pattern of higher stocks of CDW in the plateau, where the soil is more structured, deeper, and less physically restricted and where AGB stocks are greater (Martins et al., 2014). On the other hand, at the TAP site, the peaks of CDW stocks appears to be more spatially disaggregated which might indicate that CDW is associated with natural, small-scale disturbance (Rice et al., 2004). For degraded forest, in the Fazenda Tanguro site we found no published data on CDW, but the increase in CDW after the repeated fire events agrees with previous studies (Gerwing, 2002). Finally, the effect of logging (1.5-fold increase) on CDW stocks at the landscape level at the CAU site is similar in magnitude to our earlier field studies (Keller et al., 2004).

\subsection{Implications for studies of the Amazon carbon budget}

Our results demonstrate that small-footprint airborne lidar remote sensing can be used to reduce the uncertainty of the spatial distribution of CDW stocks across intact and degraded Amazonian forests. Our approach required systematic classification of the Amazonian forests into intact, logged, and 
burned conditions. More complex models using regression trees may eventually combine classification and CDW estimation using lidar data. We avoided more complex models in this study because our simple regression models are more transparent and less likely to suffer from overfitting because they rely on few predictors. Models for the estimation of CDW using lidar data only are likely to be less accurate than models for total AGB when relative uncertainty is compared (e.g., Longo et al., 2016). However, because the absolute values of CDW are usually in the range of $10 \%$ to $20 \%$ of AGB except at heavily degraded sites, the absolute uncertainties for CDW are still likely to be smaller than the absolute uncertainties for AGB.

For any extrapolation approach, it is critical to avoid bias. Overall, we found little bias in our models for the estimation of CDW across forest sites and disturbances types. Nonetheless, we raise two potential concerns. First, in intact forests of the southern Amazon, the stocks of CDW are considerably lower than in the central and eastern Amazon. This reflects the smaller biomass stocks and lower wood densities found in that region (Nogueira et al., 2007). Second, in heavily burned forests (more than three events of fire) the in situ estimates of CDW stocks were well below the airborne-lidarpredicted values, probably because CDW was consumed in the fires. We note that forest degradation from repeated fires is concentrated along the eastern edge of the Brazilian arc of deforestation (Morton et al., 2013).
Improved knowledge of the spatial distribution of CDW stocks complementing our growing knowledge of aboveground live biomass distributions will reduce the uncertainties of emissions from deforestation and forest degradation (Aguiar et al., 2012). We highlight that CDW is relatively more abundant in degraded than in intact forests. Airborne lidar is a valuable tool for estimates of the impact of forest degradation on the carbon cycle, and our work has the potential to expand understanding beyond the current lidar approaches that focus exclusively on aboveground biomass. Further development of the approach presented here may be applied to more extensive and systematic airborne lidar acquisitions or perhaps even spaceborne lidar from GEDI and/or ICESat-2 missions to estimate CDW across wide areas of tropical forests (Stavros et al., 2017).

Data availability. Field coarse dead wood and forest inventory data as well as lidar data are available from EMBRAPA at the following URL: https://www.paisagenslidar.cnptia.embrapa.br/webgis/ (dosSantos and Keller, 2016). 
Appendix A

\section{Reserva Ducke}

CWD map

Total CWD (Mg ha-1)

22-30

30-38

$38-41$

$\square$ 41-44

$\square 44-46$

$\square 46-48$

$\square$ 48-51

$\square 51-53$

$\square 53-56$

$56-61$

Figure A1. Wall-to-wall map of total CDW and digital terrain model at the DUC site.

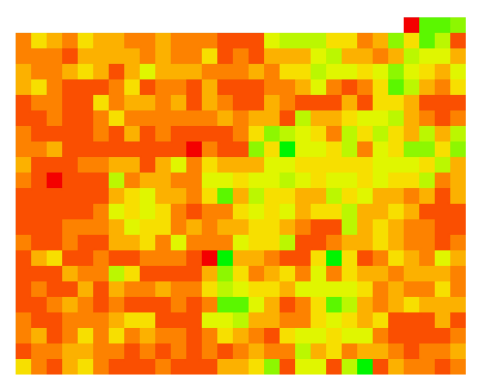

Digital terrain model

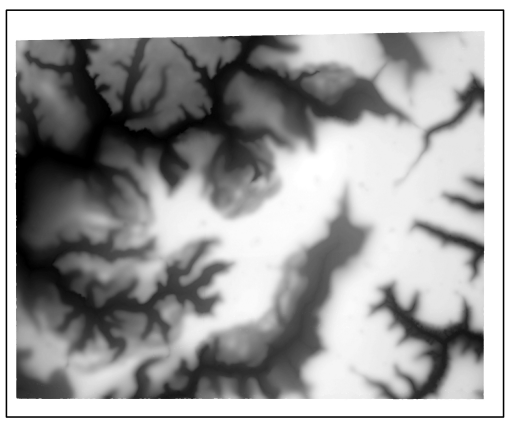

Elevation (m)

High : 107.309

Low : 37.8715 


\section{Appendix B}

Table B1. Fixed and random effects parameters of the historical scenario model for intact forests.

\begin{tabular}{lrr}
\hline Parameter (fixed effect) & Estimate & SD \\
& & \\
\hline Intercept & 3.4 & 64.3 \\
DUC site & 49.7 & 68.4 \\
FST site & 10.4 & 100.3 \\
JAM site & 1.3 & 91.4 \\
TAL site & -30.9 & 96.6 \\
TAN site & -35.6 & 104.6 \\
TAP site & -63.5 & 74.9 \\
Canopy relief ratio & 119.7 & 126.2 \\
\hline Random term (canopy relief & Estimate & \\
ratio by site; see Table 5) & & \\
\hline CAU site & 75.2 & \\
DUC site & 9.9 & \\
FST site & 119.7 & \\
JAM site & 79.6 & \\
TAL site & 119.7 & \\
TAN site & 109.7 & \\
TAP site & 324.0 & \\
\hline
\end{tabular}




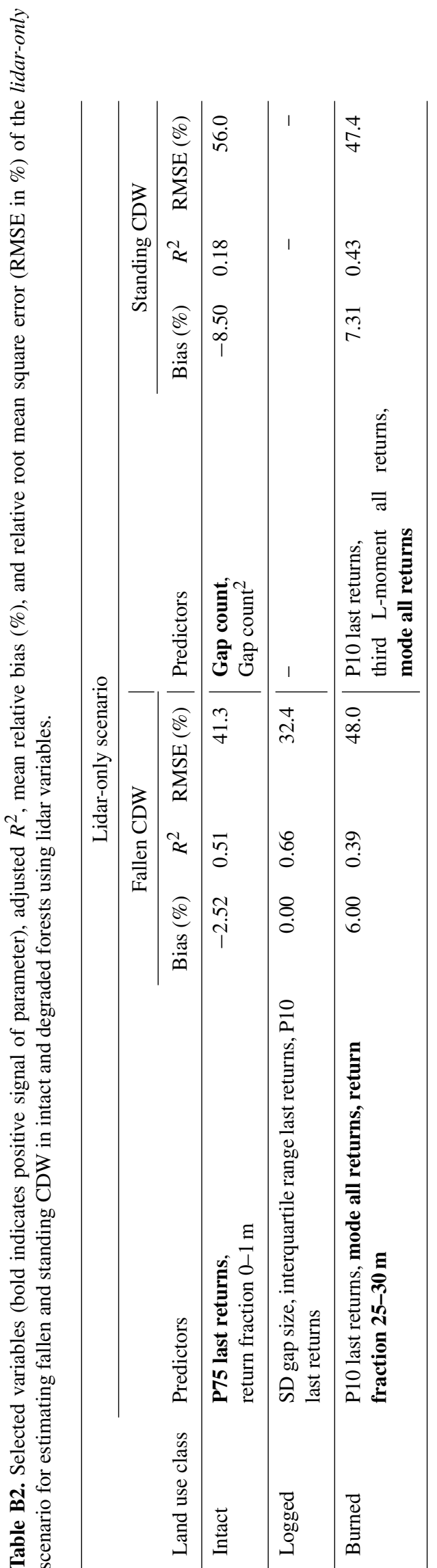

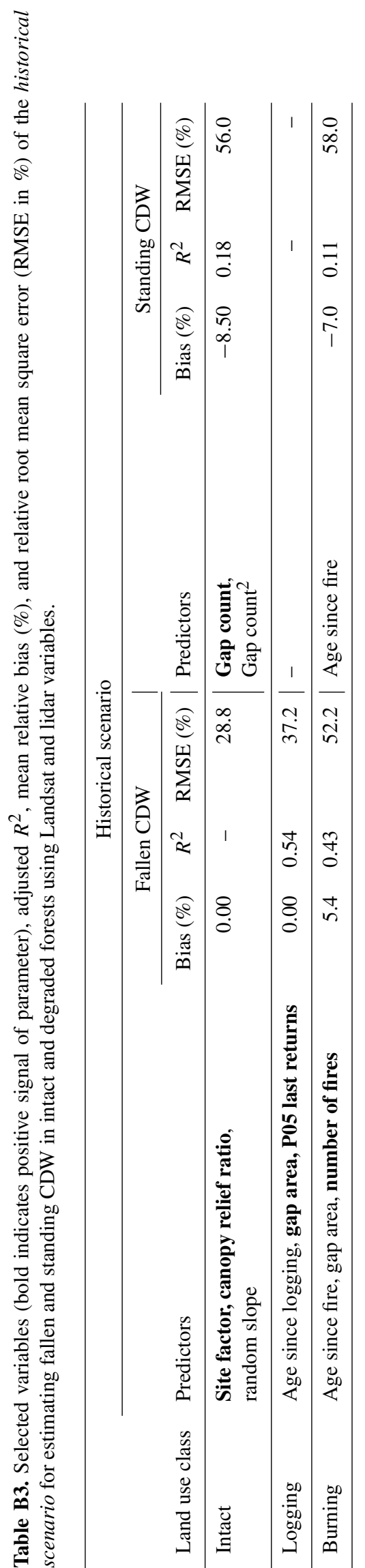

Biogeosciences, 16, 3457-3474, 2019 
Author contributions. MASS and MK designed the study. MK and MNdS coordinated the field and lidar campaigns, and MNdS analyzed the field data. MASS analyzed the field and lidar data and conducted the modeling analysis. ML provided the data on visual interpretation of Landsat imagery and assisted with modeling analysis. DCM participated in the modeling analysis. VL and ERP provided data on visual interpretation of Landsat imagery. FDBES provided the Tapajós and Reserva Adolpho Ducke field data. MASS and MK wrote the paper. All co-authors revised and approved the paper.

Competing interests. The authors declare that they have no conflict of interest.

Acknowledgements. Data were acquired by the Sustainable Landscapes Brazil project implemented by the Brazilian Agricultural Research Corporation (EMBRAPA) and the US Forest Service. The research carried out at the Jet Propulsion Laboratory, California Institute of Technology, was under a contract with the National Aeronautics and Space Administration.

Financial support. Sustainable Landscapes Brazil received financial support from USAID and the US Department of State. Aspects of this research were supported by the CNPq LBA project (grant no. 457927-2013-5), the CNPq CSF project (grant no. 457927/2013-5), and NASA's Carbon Monitoring System. Michael Keller was supported in part by the Next Generation Ecosystem Experiments-Tropics, funded by the US Department of Energy, Office of Science, Office of Biological and Environmental Research. Marcos A. S. Scaranello was supported by CNPq (fellowship grant no. 384475/2015-9). Marcos Longo was supported by FAPESP (grant no. 2015/07227-6) and by the NASA Postdoctoral Program, administered by the Universities Space Research Association under contract with NASA. Fernando Del Bon EspíritoSanto was supported by Natural Environment Research Council (NERC) grants (BIO-RED (grant no. NE/N012542/1) and AFIRE (grant no. NE/P004512/1)) and the Newton Fund ("The UK Academies/FAPESP Proc. no. 2015/50392-8 - Fellowship and Research Mobility"). Douglas C. Morton was supported by CNPq (grant no. 457927-2013-5 and the Ciência sem Fronteiras Program) and NASA's Carbon Monitoring System.

Review statement. This paper was edited by Edzo Veldkamp and reviewed by two anonymous referees.

\section{References}

Aguiar, A. P. D., Ometto, J. P., Nobre, C., Lapola, D. M., Almeida, C., Vieira, I. C., Soares, J. V., Alvala, R., Saatchi, S., Valeriano, D., and Castilla-Rubio, J. C.: Modeling the spatial and temporal heterogeneity of deforestation-driven carbon emissions: the INPE-EM framework applied to the Brazilian Amazon, Glob. Change Biol., 18, 3346-3366, https://doi.org/10.1111/j.13652486.2012.02782.x, 2012.
Alamgir, M., Campbell, M. J., Turton, S. M., Pert, P. L., Edwards, W., and Laurance, W. F.: Degraded tropical rain forests possess valuable carbon storage opportunities in a complex, forested landscape, Sci. Rep., 6, 30012, https://doi.org/10.1038/srep30012, 2016.

Andersen, H.-E., Reutebuch, S. E., McGaughey, R. J., d'Oliveira, M. V. N., and Keller, M.: Monitoring selective logging in western Amazonia with repeat lidar flights, Remote Sens. Environ., 151, 157-165, https://doi.org/10.1016/j.rse.2013.08.049, 2014.

Asner, G. P., Clark, J. K., Mascaro, J., Galindo García, G. A., Chadwick, K. D., Navarrete Encinales, D. A., Paez-Acosta, G., Cabrera Montenegro, E., Kennedy-Bowdoin, T., Duque, Á., Balaji, A., von Hildebrand, P., Maatoug, L., Phillips Bernal, J. F., Yepes Quintero, A. P., Knapp, D. E., García Dávila, M. C., Jacobson, J., and Ordóñez, M. F.: High-resolution mapping of forest carbon stocks in the Colombian Amazon, Biogeosciences, 9, 26832696, https://doi.org/10.5194/bg-9-2683-2012, 2012.

Baccini, A., Goetz, S. J., Walker, W. S., Laporte, N. T., Sun, M., Sulla-Menashe, D., Hackler, J., Beck, P. S. A., Dubayah, R., Friedl, M. A., Samanta, S., and Houghton, R. A.: Estimated carbon dioxide emissions from tropical deforestation improved by carbon-density maps, Nat. Clim. Change, 2, 182-185, https://doi.org/10.1038/nclimate1354, 2012.

Baskerville, G. L.: Use of Logarithmic Regression in the Estimation of Plant Biomass, Can. J. Forest Res., 2, 49-53, https://doi.org/10.1139/x72-009, 1972.

Berenguer, E., Ferreira, J., Gardner, T. A., Aragão, L. E. O. C., De Camargo, P. B., Cerri, C. E., Durigan, M., Oliveira, R. C. D., Vieira, I. C. G., and Barlow, J.: A large-scale field assessment of carbon stocks in human-modified tropical forests, Glob. Change Biol., 20, 3713-3726, https://doi.org/10.1111/gcb.12627, 2014.

Blanchard, S. D., Jakubowski, M. K., and Kelly, M.: ObjectBased Image Analysis of Downed Logs in Disturbed Forested Landscapes Using Lidar, Remote Sens., 3, 2420-2439, https://doi.org/10.3390/rs3112420, 2011.

Bolker, B. M., Brooks, M. E., Clark, C. J., Geange, S. W., Poulsen, J. R., Stevens, M. H. H.. and White, J.-S. S.: Generalized linear mixed models: a practical guide for ecology and evolution, Trends Ecol. Evol., 24, 127-135, https://doi.org/10.1016/j.tree.2008.10.008, 2009.

Brown, J. K.: Handbook for inventorying downed woody material, General Technical Report INT-16, U.S. Department of Agriculture, Forest Service, Intermountain Forest and Range Experiment Station, Ogden, UT, 1974.

Casas, Á., García, M., Siegel, R. B., Koltunov, A., Ramírez, C., and Ustin, S.: Burned forest characterization at singletree level with airborne laser scanning for assessing wildlife habitat, Remote Sens. Environ., 175, 231-241, https://doi.org/10.1016/j.rse.2015.12.044, 2016.

Chambers, J. Q., Higuchi, N., Schimel, J. P., Ferreira, L. V., and Melack, J. M.: Decomposition and carbon cycling of dead trees in tropical forests of the central Amazon, Oecologia, 122, 380 388, 2000.

Chao, K.-J., Phillips, O. L., Baker, T. R., Peacock, J., LopezGonzalez, G., Vásquez Martínez, R., Monteagudo, A., and Torres-Lezama, A.: After trees die: quantities and determinants of necromass across Amazonia, Biogeosciences, 6, 1615-1626, https://doi.org/10.5194/bg-6-1615-2009, 2009. 
Cochrane, M. A.: Fire science for rainforests, Nature, 421, 913-919, 2003.

Cochrane, M., Alencar, A., Schulze, M. D., Souza Jr., Nepstad, D., Lefebvre, P., and Davidson, E. A.: Positive Feedbacks in the Fire Dynamic of Closed Canopy Tropical Forests, Science, 284, 1832-1835, 1999.

Cook, B., Corp, L., Nelson, R., Middleton, E., Morton, D., McCorkel, J., Masek, J., Ranson, K., Ly, V., and Montesano, P.: NASA Goddard's LiDAR, Hyperspectral and Thermal (G-LiHT) Airborne Imager, Remote Sens., 5, 4045-4066, https://doi.org/10.3390/rs5084045, 2013.

dos-Santos, M. N. and Keller, M.: Sustainable Landscapes Brazil, available at: https://www.paisagenslidar.cnptia.embrapa. br/webgis/ (last access: 3 September 2019), 2016.

Espírito-Santo, F. D. B., Keller, M. M., Linder, E., Oliveira Junior, R. C., Pereira, C., and Oliveira, C. G.: Gap formation and carbon cycling in the Brazilian Amazon: measurement using high-resolution optical remote sensing and studies in large forest plots, Plant Ecol. Divers., 7, 305-318, https://doi.org/10.1080/17550874.2013.795629, 2014a.

Espírito-Santo, F. D. B., Gloor, M., Keller, M., Malhi, Y., Saatchi, S., Nelson, B., Junior, R. C. O., Pereira, C., Lloyd, J., Frolking, S., Palace, M., Shimabukuro, Y. E., Duarte, V., Mendoza, A. M., López-González, G., Baker, T. R., Feldpausch, T. R., Brienen, R. J. W., Asner, G. P., Boyd, D. S., and Phillips, O. L.: Size and frequency of natural forest disturbances and the Amazon forest carbon balance, Nat. Commun., 5, 3434, https://doi.org/10.1038/ncomms4434, 2014b.

Gerwing, J. J.: Degradation of forests through logging and fire in the eastern Brazilian Amazon, Forest Ecol. Manag., 157, 131$141,2002$.

Harmon, M., Whigham, D., Sexton, J., and Olmsted, I.: Decomposition and Mass of Woody Detritus in the Dry Tropical Forests of the Northeastern Yucatan Peninsula, Mexico, Biotropica, 27, 305-316, 1995.

Harmon, M. E., Franklin, J. F., Swanson, F. J., Sollins, P., Cline, P., Aumen, N. G., Sedell, J. R., Lienkaemper, G. W., Cromack, K., and Cummins, K. W.: Ecology of Coarse Woody Debris in Temperate Ecosystems, Adv. Ecol. Res., 15, p. 170, 1986.

Hayek, M. N., Longo, M., Wu, J., Smith, M. N., Restrepo-Coupe, N., Tapajós, R., da Silva, R., Fitzjarrald, D. R., Camargo, P. B., Hutyra, L. R., Alves, L. F., Daube, B., Munger, J. W., Wiedemann, K. T., Saleska, S. R., and Wofsy, S. C.: Carbon exchange in an Amazon forest: from hours to years, Biogeosciences, 15, 4833-4848, https://doi.org/10.5194/bg-15-4833-2018, 2018.

Hosking, J. R. M.: L-Moments: Analysis and Estimation of Distributions Using Linear Combinations of Order Statistics, J. R. Stat. Soc. Ser. B, 52, 105-124, 1990.

Hunter, M. O., Keller, M., Victoria, D., and Morton, D. C.: Tree height and tropical forest biomass estimation, Biogeosciences, 10, 8385-8399, https://doi.org/10.5194/bg-10-8385-2013, 2013.

Hunter, M. O., Keller, M., Morton, D., Cook, B., Lefsky, M., Ducey, M., Saleska, S., de Oliveira, R. C., and Schietti, J.: Structural Dynamics of Tropical Moist Forest Gaps, edited by R. Zang, PLOS ONE, 10, e0132144, https://doi.org/10.1371/journal.pone.0132144, 2015.

Keller, M., Palace, M., Asner, G. P., Pereira, R., and Silva, J. N. M.: Coarse woody debris in undisturbed and logged forests in the eastern Brazilian Amazon, Glob. Change Biol., 10, 784-795, https://doi.org/10.1111/j.1529-8817.2003.00770.x, 2004.

Leitold, V., Keller, M., Morton, D. C., Cook, B. D., and Shimabukuro, Y. E.: Airborne lidar-based estimates of tropical forest structure in complex terrain: opportunities and trade-offs for REDD+, Carbon Balance Manag., 10, 3, https://doi.org/10.1186/s13021-015-0013-x, 2015.

Leitold, V., Morton, D. C., Longo, M., dos-Santos, M. N., Keller, M., and Scaranello, M.: El Niño drought increased canopy turnover in Amazon forests, New Phytol., 219, 959-971, https://doi.org/10.1111/nph.15110, 2018.

Longo, M., Keller, M., dos-Santos, M. N., Leitold, V., Pinagé, E. R., Baccini, A., Saatchi, S., Nogueira, E. M., Batistella, M., and Morton, D. C.: Aboveground biomass variability across intact and degraded forests in the Brazilian Amazon, Global Biogeochem. Cy., 30, 1639-1660, https://doi.org/10.1002/2016GB005465, 2016.

Marchi, N., Pirotti, F., and Lingua, E.: Airborne and Terrestrial Laser Scanning Data for the Assessment of Standing and Lying Deadwood: Current Situation and New Perspectives, Remote Sens., 10, 1356, https://doi.org/10.3390/rs10091356, 2018.

Martins, D. L., Schietti, J., Feldpausch, T. R., Luizão, F. J., Phillips, O. L., Andrade, A., Castilho, C. V., Laurance, S. G., Oliveira, Á., Amaral, I. L., Toledo, J. J., Lugli, L. F., Veiga Pinto, J. L. P., Oblitas Mendoza, E. M., and Quesada, C. A.: Soilinduced impacts on forest structure drive coarse woody debris stocks across central Amazonia, Plant Ecol. Divers., 8, 229-241, https://doi.org/10.1080/17550874.2013.879942, 2015.

Martinuzzi, S., Vierling, L. A., Gould, W. A., Falkowski, M. J., Evans, J. S., Hudak, A. T., and Vierling, K. T.: Mapping snags and understory shrubs for a LiDAR-based assessment of wildlife habitat suitability, Remote Sens. Environ., 113, 25332546, https://doi.org/10.1016/j.rse.2009.07.002, 2009.

McDowell, N., Allen, C. D., Anderson-Teixeira, K., Brando, P., Brienen, R., Chambers, J., Christoffersen, B., Davies, S., Doughty, C., Duque, A., Espirito-Santo, F., Fisher, R., Fontes, C. G., Galbraith, D., Goodsman, D., Grossiord, C., Hartmann, H., Holm, J., Johnson, D. J., Kassim, A. R., Keller, M., Koven, C., Kueppers, L., Kumagai, T., Malhi, Y., McMahon, S. M., Mencuccini, M., Meir, P., Moorcroft, P., Muller-Landau, H. C., Phillips, O. L., Powell, T., Sierra, C. A., Sperry, J., Warren, J., $\mathrm{Xu}, \mathrm{C}$., and $\mathrm{Xu}, \mathrm{X}$. : Drivers and mechanisms of tree mortality in moist tropical forests, New Phytol., 219, 851-869, https://doi.org/10.1111/nph.15027, 2018.

McGaughey, R. J.: FUSION/LDV: Software for LIDAR Data Analysis and Visualization, USFS Pacific Northwest Research Station, Seattle, WA, USA, 2014.

Miller, A. J.: Selection of Subsets of Regression Variables, J. R. Stat. Soc. Ser. Gen., 147, 389-425, https://doi.org/10.2307/2981576, 1984.

Morton, D. C., Le Page, Y., DeFries, R., Collatz, G. J., and Hurtt, G. C.: Understorey fire frequency and the fate of burned forests in southern Amazonia, Philos. T. R. Soc. B, 368, 20120163 , https://doi.org/10.1098/rstb.2012.0163, 2013.

Næsset, E., Gobakken, T., and Nelson, R.: Sampling and mapping forest volume and biomass using airborne LIDARs, Proc. Eighth Annu. For. Inventory Anal. Symp., available at: http:// www.treesearch.fs.fed.us/pubs/download/17320.pdf (last access: 12 June 2017), 2006. 
Nelson, R.: Model effects on GLAS-based regional estimates of forest biomass and carbon, Int. J. Remote Sens., 31, 1359-1372, https://doi.org/10.1080/01431160903380557, 2010.

Nelson, R., Krabill, W., and Tonelli, J.: Estimating forest biomass and volume using airborne laser data, Remote Sens. Environ., 24, 247-267, https://doi.org/10.1016/0034-4257(88)90028-4, 1988.

Nogueira, E. M., Fearnside, P. M., Nelson, B. W., and França, M. B.: Wood density in forests of Brazil's "arc of deforestation": Implications for biomass and flux of carbon from landuse change in Amazonia, Forest Ecol. Manag., 248, 119-135, https://doi.org/10.1016/j.foreco.2007.04.047, 2007.

Palace, M., Keller, M., Asner, G. P., Silva, J. N. M., and Passos, C.: Necromass in undisturbed and logged forests in the Brazilian Amazon, Forest Ecol. Manag., 238, 309-318, https://doi.org/10.1016/j.foreco.2006.10.026, 2007.

Palace, M., Keller, M., and Silva, H.: Necromass production: studies in undisturbed and logged Amazon forests, Ecol. Appl., 18, 873884, 2008.

Palace, M., Hurtt, G., Keller, M., and Frolking, S.: A review of above ground necromass in tropical forests, INTECH Open Access Publisher, availableat: https://www.researchgate.net/profile/ (last access: 28 March 2016), 2012.

Pan, Y., Birdsey, R. A., Fang, J., Houghton, R., Kauppi, P. E., Kurz, W. A., Phillips, O. L., Shvidenko, A., Lewis, S. L., Canadell, J. G., Ciais, P., Jackson, R. B., Pacala, S. W., McGuire, A. D., Piao, S., Rautiainen, A., Sitch, S., and Hayes, D.: A Large and Persistent Carbon Sink in the World's Forests, Science, 333, 988993, https://doi.org/10.1126/science.1201609, 2011.

Parker, G. G. and Russ, M. E.: The canopy surface and stand development: assessing forest canopy structure and complexity with near-surface altimetry, Forest Ecol. Manag., 189, 307-315, https://doi.org/10.1016/j.foreco.2003.09.001, 2004.

Pesonen, A., Maltamo, M., Eerikäinen, K., and Packalèn, P.: Airborne laser scanning-based prediction of coarse woody debris volumes in a conservation area, Forest Ecol. Manag., 255, 32883296, https://doi.org/10.1016/j.foreco.2008.02.017, 2008.

Pinheiro, J. and Bates, D. M.: Mixed-effects models in $\mathrm{S}$ and S-PLUS, Springer New York, New York, NY, https://doi.org/10.1007/b98882, 2000.

Polewski, P., Yao, W., Heurich, M., Krzystek, P., and Stilla, U.: Detection of fallen trees in ALS point clouds using a Normalized Cut approach trained by simulation, ISPRS J. Photogramm. Remote Sens., 105, 252-271, https://doi.org/10.1016/j.isprsjprs.2015.01.010, 2015.
PRODES-INPE: Projeto PRODES: monitoramento da floresta amazônica brasileira por satélite, available at: http://www.obt. inpe.br/prodes/ (last access: 1 April 2017), 2016.

Pyle, E. H., Santoni, G. W., Nascimento, H. E. M., Hutyra, L. R., Vieira, S., Curran, D. J., van Haren, J., Saleska, S. R., Chow, V. Y., Camargo, P. B., Laurance, W. F., and Wofsy, S. C.: Dynamics of carbon, biomass, and structure in two Amazonian forests, J. Geophys. Res.-Biogeo., 113, G00B08, https://doi.org/10.1029/2007JG000592, 2008.

R Core Team: R: A language and environment for statistical computing., R Foundation for Statistical Computing, Vienna, Austria, available at: https://www.R-project.org/ (last access: 3 September 2019), 2017.

Rappaport, D. I., Morton, D. C., Longo, M., Keller, M., Dubayah, R., and dos-Santos, M. N.: Quantifying long-term changes in carbon stocks and forest structure from Amazon forest degradation, Environ. Res. Lett., 13, 065013, https://doi.org/10.1088/17489326/aac331, 2018.

Réjou-Méchain, M., Tymen, B., Blanc, L., Fauset, S., Feldpausch, T. R., Monteagudo, A., Phillips, O. L., Richard, H., and Chave, J.: Using repeated small-footprint LiDAR acquisitions to infer spatial and temporal variations of a highbiomass Neotropical forest, Remote Sens. Environ., 169, 93101, https://doi.org/10.1016/j.rse.2015.08.001, 2015.

Rice, A. H., Pyle, E. H., Saleska, S. R., Hutyra, L., Palace, M., Keller, M., de Camargo, P. B., Portilho, K., Marques, D. F., and Wofsy, S. C.: Carbon balance and vegetation dynamics in an oldgrowth Amazonian forest, Ecol. Appl., 14, 55-71, 2004.

Saatchi, S. S., Harris, N. L., Brown, S., Lefsky, M., Mitchard, E. T. A., Salas, W., Zutta, B. R., Buermann, W., Lewis, S. L., Hagen, S., Petrova, S., White, L., Silman, M., and Morel, A.: Benchmark map of forest carbon stocks in tropical regions across three continents, P. Natl. Acad. Sci. USA, 108, 98999904, https://doi.org/10.1073/pnas.1019576108, 2011.

Schimel, D., Stephens, B. B., and Fisher, J. B.: Effect of increasing $\mathrm{CO}_{2}$ on the terrestrial carbon cycle, P. Natl. Acad. Sci. USA, 112, 436-441, https://doi.org/10.1073/pnas.1407302112, 2015.

Stavros, E. N., Schimel, D., Pavlick, R., Serbin, S., Swann, A., Duncanson, L., Fisher, J. B., Fassnacht, F., Ustin, S., Dubayah, R., Schweiger, A., and Wennberg, P.: ISS observations offer insights into plant function, Nat. Ecol. Evol., 1, 0194, https://doi.org/10.1038/s41559-017-0194, 2017. 